\title{
旧長崎大司教館における建築工事の実態 \\ A REPORT ON THE BUILDING CONSTRUCTION WORK \\ AT THE FORMER HOUSE OF THE ARCHBISHOP OF NAGASAKI
}

\author{
喜田信代*, 羽深久夫** \\ Nobuyo KITA and Hisao HABUKA
}

\begin{abstract}
The Former House of the archbishop of Nagasaki construction work entailed the construction of a stone wall behind the Former House of archbishop, and the new construction of servants' quarters, toilets, and a basement. These were incidental to the work of the Former House of Archbishop, which was then performed.

Yosuke Tetsukawa, an attorney of the construction team, signed contractual agreements with the contractors and supervised the construction work. The construction cost exceeded 16,997.553 yen, with cash payments made prior to September 16, 1913.

The construction costing employed an actual cost plus free contract system. The construction period spanned five years, with the plan commencing in 1910, and the construction being completed around March 1915.
\end{abstract}

\section{Keywords : Former House of the archbishop of Nagasaki, Yosuke Tetsukawa, Construction work contract, Cost plus fee contract system, Cost of construction 旧長崎大司教館，鉄川與助，建築工事請負契約，実費精算方式，建築工事費}

\section{1. はじめに}

長崎市南山手町の国指定史跡大浦天主堂境内には、国宝の大浦天 主堂 $(\text { 元治元年 } / 1864)^{1)}$ 、重要文化財の旧羅典神学校 (明治 8 年 $/ 1875$, 設計ド・ロ神父 ${ }^{2)}$ ，施工者不詳 $)^{3)}$ 、長崎県指定文化財の旧長崎大司 教館 (大正 4 年/1915, 設計ド・ロ神父と鉄川與助) ${ }^{4}$, 施工鉄川與 助 $)^{5)}$ (以後、司教館と表記) と旧伝道師学校（旧聖婢会本部） ${ }^{6)}$ が ある (写真 1$)$ 。

鉄川與助 (1879〜1976) （以後、與助と表記）は、明治 39(1903) 年 に鉄川組を興し、同年には桐古天主堂改修工事 (明治 39 年/1903)に 従事し、桐古天主堂改修工事中に、冷水天主堂(明治 40 年/1905)の 構造を木造にすることを決め、冷水天主堂 (明治 40 年/1905) と、奈

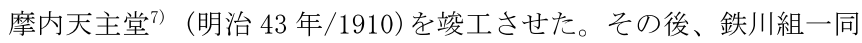
を引き連れて九州本土に進出し、佐賀市公教会 (明治 43 年/1910) と 今村天主堂新築工事 (大正 2 年/1913) を竣工させ、大正 2 年 (1913)に 大浦天主堂工事係代人 ${ }^{8)}$ として、司教館工事に従事している ${ }^{9)}$ 。

現状の司教館は、北側立面の最下部の一部が地下室になっている 地上 3 階建 (但し 3 階は屋根裏利用)の煉瓦造で、長崎司教区の本部 として建築されている ${ }^{10)}$ 。東西の両方の 1 階と 2 階にベランダがあ り、内部は南北の大部屋を中廊下で結び、中央の西側には階段があ り、1 階と 2 階の各部屋には中廊下で通じている。また、司教館の 裏手にあたる西側には 2 段の石垣があり、便所と湯場がある ${ }^{11}$ 。

大正 2 年 (1913) から行われた司教館工事は、司教館の基礎工事と もなる地下室 ${ }^{12)}$ 工事と、司教館裏手の整地作業で出来た土地に、小 使住宅と便所並びに湯場を新築する工事を含んでいる。近年、長崎 県、並びに長崎市において実測調查が行われているが、司教館工事 の詳細については明らかにされていない13)。

司教館は、大浦天主堂境内の北斜面に、地形を利用して建築され、 北側の表通りに面した地下室は地上階に見える。

また、司教館は、倉庫としての地下室と、1 階は司教の事務室や応 接室、ならびに食堂と厨房で、2 階は司教の部屋と各神父の個室、3 階は司教館に集う神父の宿泊施設といわれており、司教の事務室と 神父の宿舎を兼㸚た建築であった。この他、司教館と、その上段に ある旧羅典神学校（明治 8 年/1875) は、共にド・ロ神父の設計であ る。明治初期から後期まで、主に長崎県内で宣教活動に従事してき たド・ロ神父は、旧羅典神学校との関係を考慮して、司教館は、傾 斜地という大浦教会境内の敷地的な制約を踏まえたうえで、高低差 を利用し、遠方からも存在感のある建築になるように、煉瓦造で一 部地下室のある 3 階建にしたのではないかと考えられる。

司教館工事において、與助は、司教館は「司教館」や「司祭館」、 「本館」と記し、附属工事は「天主堂附属工事」や「学校附属工事」 と明記し ${ }^{14)}$ 、請負業者との間に、仕様書、請負契約書、心得書など の工事請負契約関係書類を取交し、工事費の精算には現金での支払 の他に、支払伝票 ${ }^{15)}$ を用いている。また、史料に「附属工事用」と 書かれた注文書で発注・納品された建築材料は、附属工事をはるか

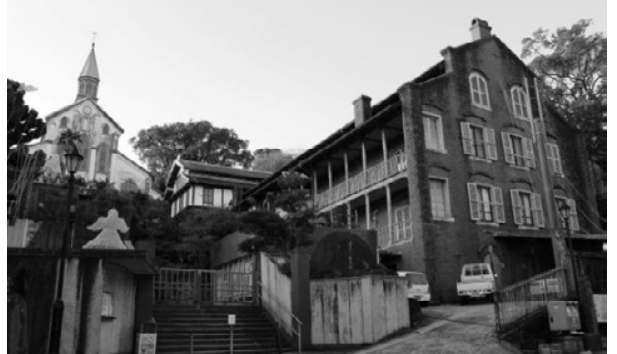

写真 1 大浦天主堂境内北側景観

写真は、敷地では西側にあたる右端から旧長崎大司教館、中央は旧羅典神学校、 左端は大浦天主堂と、大浦天主堂の裹手の高台には旧伝道師学校 (旧聖婢会本部) がある。旧長崎大司教館は大正 4 年 (1915) に竣工しているが、大正 2 年 (1913) に は旧長崎大司教館の北側立面の最下部にあたる地下室と、裏手には石垣を造成 し、小使住宅と便所・湯場を建築していた。現在は、小使住宅は解体されている。

に凌ぐ数量であること から、主な材料につい て検討した処、司教館 工事分と併せたもので、 「附属工事」とは司教 館の基礎工事、或いは 前段階の工事と推定で きる。

\footnotetext{
* 札幌市立大学大学院デザイン研究科 博士後期課程 $\cdot$ 修士 (学術)

** 札幌市立大学大学院デザイン研究科 教授・博士 (工学)
}

Graduate Student, Graduate School of Design, Sapporo City University, M.A.

Prof., Graduate School of Design, Sapporo City University, Dr. Eng. 
筆者等は、既往の研究において、與助が鉄川組を創業後、桐古天 主堂改修工事 (明治 39 年/1903) から今村天主堂新築工事 (大正 2 年 /1913)の工事内容、工事工程、請負内容、工事費の精算方式につい て纏めてきた。司教館工事では、與助は天主堂工事係代人として請 負業者と関係書類を取交し、工事を管理している。

洋風建築導入後である明治後期は、建築工事請負の受注形式や契 約方式、建築工事の工程管理と工事費清算方法は変遷過程にあり、 請負の形態も、棟梁などの専門的技術者のみならず、資本家の参入 があり、請負業も成立過程にあった ${ }^{16)}$ 。また、請負契約の近代化を 目指し、請負契約関係書類も整備過程にあった ${ }^{17)}$ 。

本稿は、司教館工事の関連史料を検討し、大正 2 年 (1913) 〜大正 4 年 (1915) に行われた司教館工事の工事請負契約関係書類、工事内 容と建築工事費、ならびに工事工程を明らかにする。すなわち、與 助は、九州地方の民間工事といえる天主堂工事で、中央における請 負契約と変わらない近代的な請負を同時期に実施していたことを明 らかにすることにつながる。

\section{2. 史料について}

表 1 は、左列から史料番号、年月日、書類の題目、工事区分、工 事・材料、数量、請負又は契約(円)、書類の宛先 ${ }^{18)}$ と差出人、割印、 体裁 $(\mathrm{mm})$ 、備考を表わしている。史料は、司教館工事の関係史料 17 件で、年月日は大正 2 (1913) 年 5 月 23 日〜大正 4 (1915) 年 3 月 25 日まである。書類の題目は、見積書、契約証、仕様書、請負者心得、 一式請負人心得書と証書式、建築材料納方請負人心得書と証書式、 工手間請負人心得書、領収書、手紙、預り証、支払伝票で、工事区 分は、記載内容から、司教館工事並びに司教館附属工事に分けられ る。工事・材料および請負又は契約(円）は、司教館工事並びに司教 館附属工事の材料と、請負金を示したもので、史料に署名押印や割 印があるものは、実際に使われた書類と考えられる。また、見積書 および仕様書には「図面仕様書の通り」とあるが、図面については 未確認である。

なお、本稿において使用するのは與助の五男・喜一郎氏が保有す る史料である19)。

表 1 旧長崎大司教館の建築工事の関係史料

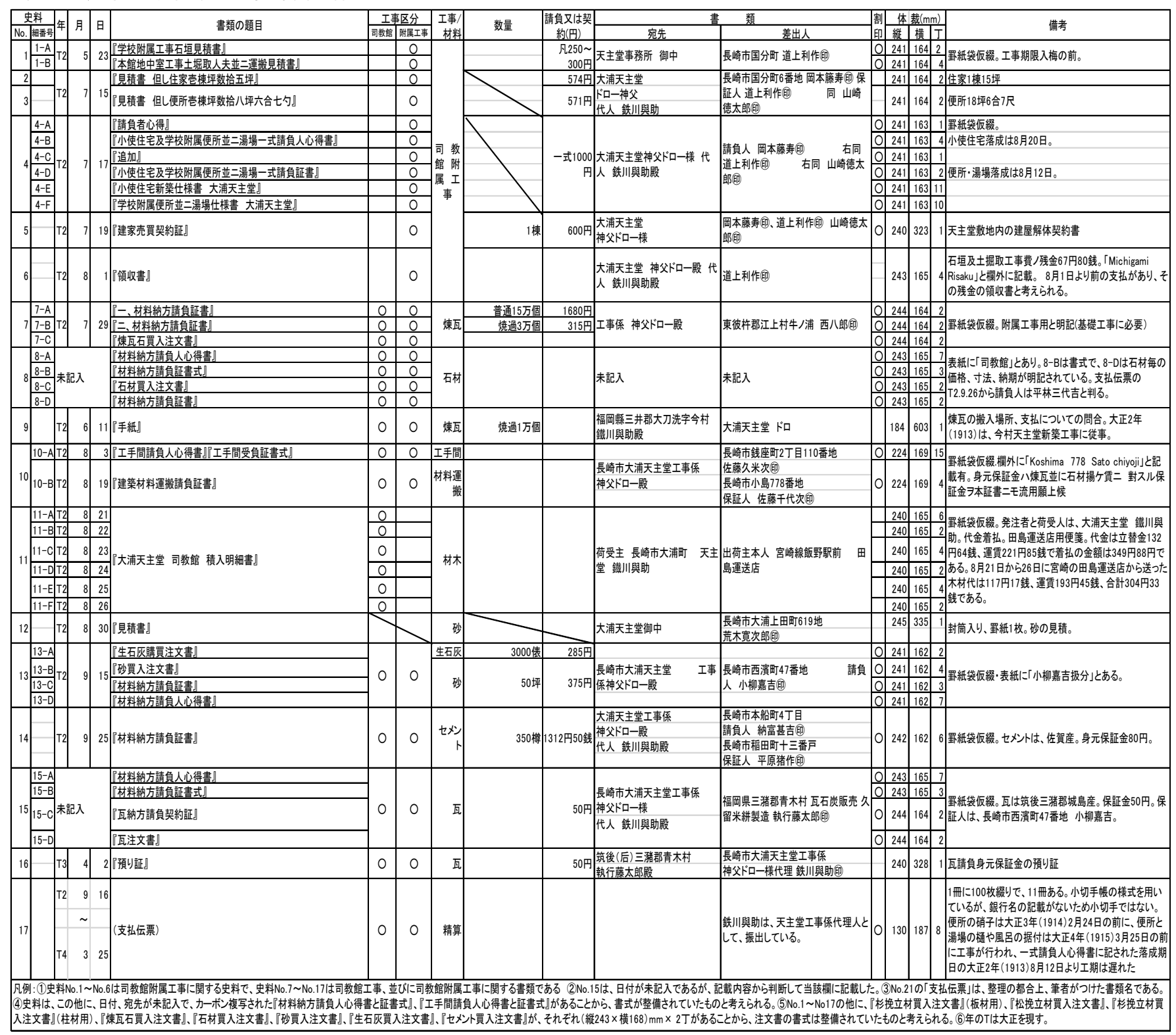




\section{（1）見積書}

No. 1『学校附属工事石垣見積書』(1-A) は、石原価、運搬賃、石 工手間賃、石工手間賃及び土掘取人夫賃の見積で、『本館地中室工事 土掘取人夫並二運搬見積書』(1-B) は、地下室工事の土掘取と運搬 の見積で、工事費は凡そ 250 260 円の見込みで、完成予定は 6 月の 入梅前である。日付はともに大正 2 年（1913） 5 月 23 日である。

No. 2『見積書 但し住宅壱棟坪数拾五坪』は、住宅1棟15坪、見積 金額は574円、No. 3『見積書 但し便所壱棟坪数拾八坪六合七勺』は、 便所 1 棟坪数 18 坪 6 合 7 勺、見積金額は 571 円で、日付はともに大 正 2 年（1913） 7 月 15 日である。

No. 12『見積書』は、大正 2 年（1913）8月 30 日付で、砂 1 坪 13 円の見積書である。

\section{（2）請負契約書}

No. 5 『建屋売買契約証』は、大正 2 年（1913） 7 月 19 日付で、天 主堂境内の既存の建屋 1 棟 600 円の売買契約書で、契約当日に代金 を支払い、8月 12 日から解家に着手し、9月 1 日に材料全部を取り 除く契約である。契約には「石材全部及び備品を除く」と但書があ ることから、建屋には石材も使われており、備品が備わっていたこ とが判る20)。

\section{(3) 仕様書}

『小使住宅新築仕様書 大浦天主堂』 ${ }^{21)}(4-E)$ は、15 坪木造住宅 1 棟の屋根は瓦莫で、2 坪 5 合の室 6 室の建築概要と仕様が記され ている。『学校附属便所并二湯場仕様書 大浦天主堂』22) (4-F) は、 18 坪 6 合 7 勺の便所と湯場の建築概要と仕様が記されている。

心得書は、一式請負人心得書と、材料納方請負人心得書、並びに 工手間請負人心得書がある。工事の場所を「長崎市大浦南山手乙壱 番地」とした上で、それぞれの心得書の後尾には、証書式が記され ている。各条項はカーボンで複写されており、『家屋建築実例』23) と同文である。

\section{1) 一式請負人心得書と証書式}

No. 4『請負者心得』 ${ }^{24)}(4-A)$ は、 5 項目の大工の心得が記されたも ので、請負人に対する条件提示といえる。『小使住宅及学校附属便所 并二湯場一式請負人心得書』 $\left.{ }^{25}\right)(4-B)$ は、請負人心得を 11 力条で示 したもので、便所と湯場は 8 月 12 日、小使住宅は 8 月 20 日と落成 期日が記されている。『追加』(4-C) は、煉瓦と石材と土の材料支給 と工事の仕上げで、手間及びトロの負担は請負金から出すと補足し ている。『小使住宅及学校附属便所并二湯場一式請負証書』26) (4-D) (写真 2) (写真 3) は、小使住宅と便所・湯場の見積合計は 1,145 円になるが、2 件の工事を一式 1,000 円で契約し、図面及び仕様書に 従い、大浦天主堂工事請負人心得書 27$)$ を守る請負契約である。

\section{2) 『材料納方請負人心得書』と『材料納方請負証書式』}

石材 (8-A)、生石灰と砂 (13-D)、瓦 (15-A)の『材料納方請負人心 得書』28) 15 条からなり、請負にあたっては保証人と保証品をたて、 違約の場合の補償と責任も定めている。『材料納方請負証書式』29) (8-B)、(15-B) は、請負金額、内訳、材料種別、個数、納入期限、身 元保証品を記入する書式で、請負に際しては材料納方請負人心得書 を遵守するとし、納入期限と、違違の場合の違約金と保証人を定め ている。

\section{3）『工手間請負人心得書』と『エ手間請負証書式』}

『工手間請負人心得書』は 19 条で、『工手間請負証書式』30)

(10-A) は、大正 2 年 (1913) 8 月 3 日付で、請負にあたっては保証人 と保証品を差入れ、工手間請負人心得を遵守寸るとしている。工手 間請負金は、凡 240 円である

\section{（4）建築材料運搬請負証書}

『建築材料運搬請負証書』 ${ }^{31}$ （10-B)（写真 4) は大正 2 年 (1913) 8 月 19 日付で、司教館工事現場の状況に則して、停車場から天主堂工 事現場までの 5 通りの運搬経路と運賃を定めた司教館工事固有の請 負契約で、請負人は保証人を立てている。なお、身元保証金は煉瓦、 並びに石材揚賃にも流用と願い出ていることから、(10-B) は木材運 搬請負に際して作成され、煉瓦と石材の運搬請負も流用されたもの と考えられる。

\section{(5) 建築材料関係史料}

煉瓦 (No. 7) 、石材 (No. 8) 、木材 (No. 11)、生石灰と砂 (No. 13)、セ メント (No. 14)、瓦(No. 15) は、それぞれ材料別に、請負業者から材 料納方請負証書、もしくは積入明細書が提出されている。

\section{1)『材料納方請負証書』並びに『積入明細書』}

(1) 煉瓦 No. 7 の『材料納方請負証書』(7-A) は普通煉瓦 15 万個、

『材料納方請負証書』(7-B) は焼過煉瓦 3 万個を牛ノ浦の西八郎 ${ }^{32}$ が納入する材料納方請負証書で、納期及び違約の場合の違約金が記 されている。

『煉瓦石買入注文書』 ${ }^{33)}$ (7-C) は、焼過煉瓦 3 万個と普通煉瓦普 通煉瓦 15 万個の寸法、品質を規定、注文数を記している。

(2) 石材 No. 8 の『石材買入注文書』 ${ }^{34)}(8-\mathrm{C})$ は、石材は肥前北高 来郡の田結 $\left.{ }^{35}\right)$ 産と指定し、楷段石、入口敷居石、空血石、沓石、地 覆石、迫石のそれぞれの納期と検査について記している。

『材料納方請負証書』(8-D) は、(8-C)の注文品の単価と寸法を明 記し、納期限は注文書の通りとしている。なお、No. 8 の 8-A〜8-D には、日付、請負人の住所・氏名は未記載であるが、No. 20『支払伝 票』から平林三代吉と判る ${ }^{36)}$ 。

(3) 木材 No. 11『大浦天主堂司教館 積入明細書』(11-A～11-F) は、 大正 2 年 (1913) 8 月 21 日〜26 日までの木材の送状で、荷受主は長 崎市大浦町天主堂鐵川與助、出荷主は本人であり、宮崎線飯野駅前 田島運送店の扱で代金は着払である。積入明細書には、木材の材種、 寸法、数量と、立替金 132 円 64 銭、運賃 221 円 85 銭で、支払合計 349 円 88 円が記されている。

(4) 生石灰と砂 No. 13 は生石灰之砂の『材料納方請負証書』である。 『生石灰購買注文書』(13-A) は、八代産 ${ }^{37)}$ の石灰 3000 俵 285 円で、 『砂買入注文書』38)（13-B）は砂凡そ 50 坪を 375 円とした契約であ る。砂はNo. 12『見積書』と見積併せをした上で、生石灰と砂は小柳 嘉吉に請負わせたと考えられる。

(5) セメント No. 14『材料納方請負証書』はセメント 350 樽で 1,312 円 50 銭の材料納方請負証書で、請負人は納富甚吉、保証人は平原猪 作で、身元保証品を添えた請負証書である。

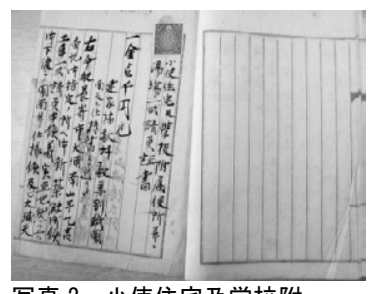

写真 2 小使住宅及学校附 属便所并二湯場一式請負証書

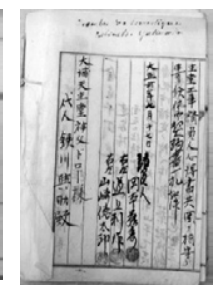

写真 3

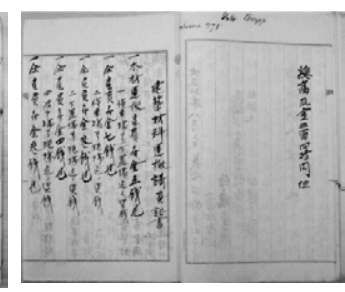

写真 4 『建築材料運搬請 負契約証』 
(6) 瓦 No. 15 は瓦で、久留米の執行藤太郎 ${ }^{39)}$ の請負で、『瓦納方請 負契約証』(15-C) は、城島瓦の形状、価格、納期、製造の方法、特 製品とし、身元保証金を記した上で、長崎市に住む小柳嘉吉を代理 としている。『瓦注文書』(15-D) は、地瓦、軒瓦、平下付、同瓦下、 瓦下割、雁振、巴、角、袖、中谷瓦の数量を記したものである。

\section{(6) 『預り証』}

No. 16『預り証』(写真 5) は、大正 3 年 (1914) 4 月 2 日付の瓦請負 身元保証金 50 円の預り証で、差出人は筑後 (后) 三潳郡青木村 執 行藤太郎で、宛先は長崎市大浦天主堂工事係 神父ドロー様代理 鉄 川與助である。

\section{（7）建築工事費清算関係史料}

No. 6 『領収書』 ${ }^{40)}$ は、大正 2 年 (1913) 8 月 1 日付の、石垣及土 掘取工事の残金 67 円 80 銭の領収書である。内訳は左官と人夫の 工手間と工事に要した材料費、及び高さ 1 尺、長さ 12 間の石垣、小 便所間仕切りと小便溜栘、下水の材料と手間賃が記されている。

No. 17 「支払伝票」(写真 6) は、大正 2 年 (1913) 9 月 16 日〜大正 4 年 (1915) 3 月 25 日までの工事費が精算された 11 冊の伝票の控で、 控部分には「鐵川」の割印がある。與助は、工事項目毎に仕分けし て支払金を精算している。

\section{（8）その他の史料}

No.9『手紙』41) (写真 7) は、大正 2 年 (1913) 6 月 10 日付で、大 浦天主堂のド・ロ神父が今村天主堂 ${ }^{42)}$ 工事に従事していた鉄川與助 に、焼過煉瓦 1 万個の支払と荷揚ついて問合せた手紙である。

尚、この他に『杉挽立材買入注文書』、『松挽立材買入注文書』、『杉 挽立材買入注文書』、『煉瓦石買入注文書』、『石材買入注文書』、『砂 買入注文書』、『生石灰買入注文書』、『セメント買入注文書』がある が、日付、数量、発注先は未記入であり、印紙、並びに署名と押印 もない43)。したがって、注文書の書式は材料毎に標準化されており、 それらの書式により発注されたものと考えられる。

また、附属工事に際して、見積書と仕様書、並びに工事請負契約 書を請負業者と取交していることから、司教館工事についても同様 の仕様書や契約書、請負契約書が存在したものと推測されるが、現 状では未確認である。

\section{3. 司教館工事の建築材料}

煉瓦と石材、及び生石灰と砂は、『材料納方 請負証書』に「附属工事用」と記されている ことから、その数量から工事場所を検討する。

\section{(1) 煉瓦}

煉瓦は、18 万個 (普通煉瓦 15 万個, 焼過煉瓦 3 万個) 発注している。そこで、表 2 に、現状 の司教館と地下室、および当初の仕様書 $(4-\mathrm{F})$ から判る便所と湯場の煉瓦の数量を積算した処、

\section{表 2 煉瓦員数調}

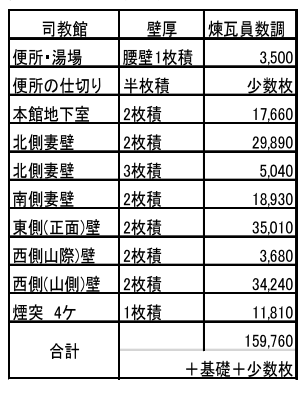

凡 159, 760 個になる ${ }^{44)}$ 。また、基礎に積まれた煉瓦の他に、便所の

したがって、18 万個の煉瓦は、司教館や地下室や、基礎部分や便所 に使われたことが判る。

\section{(2) 石材}

『材料納方請負証書』(8-D) は、階段石 $(4$ 尺 6 寸程 $\times 1$ 尺 1 寸 $\times 6$ 寸 5 分)、入口敷居 (5 寸程 $\times 1$ 尺 7 寸 $\times 6$ 寸 5 分) と入口鴨居 (5 尺 8 寸程 $\times 1$ 尺 7 寸 $\times 8$ 寸 5 分) 21 個、密血石 (4 尺 6 寸程 $\times 1$ 尺 1 寸 $\times 6$ 寸 5 分) 12 個、地覆石 (3 尺以上程 $\times 1$ 尺 $\times 6$ 寸)、沓石 ( 7 寸程 $\times 1$ 尺 $\times 1$ 寸) と (5 尺 8 寸程 $\times 6$ 寸 $\times 8$ 寸 5 分) で 70 個、迫石 (寸法未定) の請負証書である。階段石は 1 階ベランダから地下室へ降りる階段 に用いる石で、敷居、鴨居、空血石、地覆石、沓石、迫石は、いず れもその寸法と数量から司教館工事用と捉えられる。

\section{(3) 木材}

No.11『大浦天主堂 司教館 積入明細書』は、松材や栂材の納入 明細で、長さ 2 間半、2 間、1 間半の材木で、合掌束、真束、棰木、 母屋、桁行、二階、二階梁、軒桁、挟梁、方杖、隅梁など使先を記 している。したがって、これらの寸法と用途材は、小使住宅、並び に便所・湯場の材木ではなく、司教館用の材木を使先毎に買入れ、 納入する日をずらしながら搬入していたといえる。

\section{（4）生石灰と砂}

(13-C) は生石灰と砂の『材料納方請負証書』で、生石灰は、八代 産の焼立生石灰 5 貫目入 3000 俵で、砂は 50 坪分である。生石灰と 砂は、煉瓦の目地や漆喰の材料と考えられる。『和洋建築工事仕様設 計實例 上』には、「生石灰一斗八武貫五百目」で、「煉瓦石一萬本 二八三十石ノモルタルラ使用ス」とある ${ }^{45}$ が、長崎地方では従来、 天川漆喰が使われており、ド・口神父は、天川漆喰に変えて生石灰

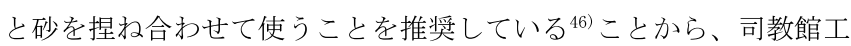
事と附属工事をあわせた材料も含まれていると考えられる。

(5) セメント

No. 14 の『材料納方請負証書』は、佐賀セメント 350 樽の材料納 方請負証書である。與助は、ド・ロ神父が推奨する調合割合として、 セメント土間叨き(セメント 1 ・砂 3 や、セメント 1 ・砂 4)、及び司

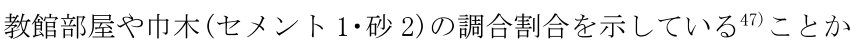
ら、セメントは司教館工事と附属工事に使われたといえる。

(6) 瓦

No. 15 は瓦の注文書で、『瓦納方請負契約証』(15-A) は、城島 ${ }^{48)}$ の中谷深形の価格、納期、製造方法、身元保証金を契約した証書で、 瓦注文書 (15-C) には、地瓦 16200 枚、軒瓦 670 枚、平下付 600 枚、 同瓦下 230 枚、瓦下割 720 枚、雁振 220 枚、巴 4 本、角 6 枚、袖 20 枚、中谷 30 枚の注文数量が発注されている。司教館の屋根は大棟に 開口部を設けるための小屋根をもち、南側は寄棟、北側は切妻であ

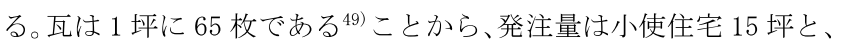
便所・湯場凡 18 坪の数量を超える 280 坪程の数量になり、司教館(平 面坪数凡そ 210 坪) と、附属工事用と併せた瓦の数量に凡そ合致す るといえる。

仕切りや溜桝、 並びに台所と 厨房の間の煉 瓦の棚や、煙 突に少数枚積 まれている。

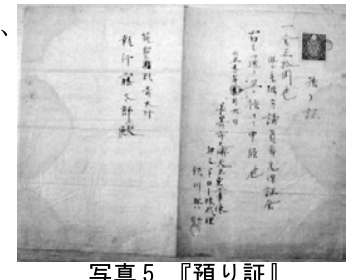

写真 5 『預り証』

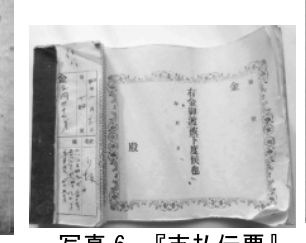

写真 6 『支払伝票』

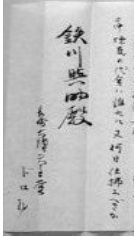

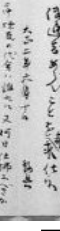

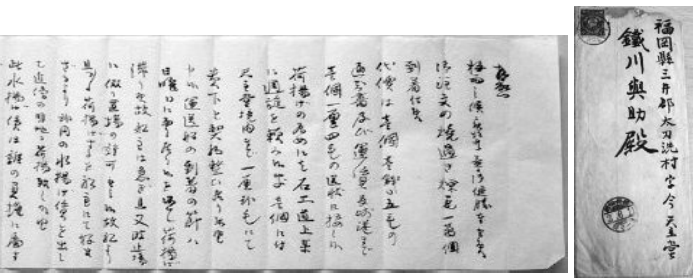

写真 7 ド・ロ神父が鉄川與助に宛てた『手紙』と封筒 


\section{（7）建築材料の発注内容}

以上の通り、(1)〜 (6)において、煉瓦、石材、木材、生石灰と砂、 セメント、瓦の発注数量を検討した処、数量的には司教館工事と附 属工事用ということが明らかになった。そこで、材料納方請負心得 書や請負証書において、「附属工事用」と発注された材料は、司教館 工事の基礎、もしく司教館工事の前に行う方が都合が良い工事に必 要な材料を、司教館工事用と区別して発注したものと考えられる。

\section{4. 司教館工事の工事内容ならびに請負契約関係書類 (1) 司教館工事の工事内容}

司教館（間口 $35.86 \mathrm{~m}$ 、奥行 $13.68 \mathrm{~m}$ 、床面積約 $490 \mathrm{~m}^{2}$ ） ${ }^{50}$ ) は、一部 地下室を有する煉瓦造 3 階建を新築する工事である。その前段に、 (1)司教館の裏手にあたる西側斜面に石垣工事を施工寸る。(2)司教館 地下室の土掘取工事を行う。(3)石垣工事で新たに造成した土地に小 使住宅 1 棟と、便所と湯場 1 棟を新築する。(4)地下室の敷地の造成 後に地下室を造る。(5)司教館新築予定地にあった既存の建屋 1 棟を 解体撤去する。(6)地下室工事終了後、司教館の 1 階から 3 階の新築 工事を行う、という工事内容になる。

\section{1）石垣工事と司教館地下室土掘取工事}

石垣工事と司教館地下室工事は、凡 250 円 260 円の見積で、請負 人は道上利作で、工事期限は入梅の前である。No.6『領収書』の工 事内訳から、石垣は、高 1 尺 長步凡 12 間であり、この土工事には、 小便所間仕切りと、小便所溜栘の工事を含んでいたことが判る。ま た、『領収書』は、大正 2 年 (1913) 8 月 1 日付であることから、工事 は入梅前、ないし 7 月末には終了していると考えられる。

\section{2）小使住宅並びに便所・湯場新築工事}

小使住宅は、建坪 15 坪(但 6 尺 3 寸畳敷ノ坪)の木造住宅 1 棟で、 2 坪 5 合の室が 6 室あり、外部は板張、内部の壁は漆喰塗、板天井 で床は板張と板畳 ${ }^{51)}$ で、屋根は棧瓦莫で、大正 2 年 (1913) 8 月 20 日に落成する請負である。学校附属便所と湯場は、建坪 18 坪 6 合 7 勺で、建築概要は、基礎は割栗地形、コンクリート打洗出で、外壁 は煉瓦の腰積、板壁、柱石は据付で、天井は無く内外共上鉋削りで、 大正 2 年 (1913) 8 月 12 日に落成の契約である。

\section{3）司教館地下室工事}

焼過煉瓦 3 万個 (7-A) の納期は、8 月 12 日〜9 月 12 日であり、普 通煉瓦 15 万個 (7-B) の納期は、 9 月 2 日〜 10 日毎に凡 6 万個である。 これにより、司教館の地下室の煉瓦工事は、大正 2 年(1913) 8 月 12 日頃に始められていたと考えられる。

\section{4）建家 1 棟解体工事}

No. 5 の大浦天主堂附属住宅壱棟の売買契約書は、天主堂内の既存 の住宅 1 棟は大正 2 年 (1913) 8 月 12 日から解家に着手し、9月 1 日 に材料全部を取り除く契約である。したがって、契約は、小使住宅 と便所・湯場の竣工後であることから、附属工事用の敷地ではなく、 司教館新築工事予定地にある住宅を解体・撤去し、その跡地を整地 したうえで、司教館を新築したと判断される。

\section{(2) 司教館工事における請負契約関係書類}

\section{1）保証金と保証品}

與助は、No. 2『見積書 但し住宅壱棟坪数拾五坪』と、No. 3『見 積書 但し便所壱棟坪数拾八坪六合七勺』の見積に、保証人を付け させ、No. 10 の工手間請負請負 (10-A) と、建築材料運搬請負 (10-B)
においても保証人を付けている。この他に、建築材料は、石材 (8-A)、 生石灰と砂（13-D）、セメント (No. 14)、瓦（15-A）の『材料納方請負 証書』と材料別に保証人と保証品をたてさせたうえで、違約の場合 の補償と責任も定めている ${ }^{52)}$ 。煉瓦の請負は実績があり、木材は、 出荷主・受取人ともに與助であることから、保証人は付けていない。

\section{2）請負契約書}

『近代日本建築学発達史』 ${ }^{53)}$ には、請負契約関係書類が実際に取 交された事例は、「明治以来、請負契約を要する大がかりな工事は、 ほとんど官公庁、もしくはそれに準ずるような大法人の発注による ものであった」として、辰野金吾等は、契約不履行など、請負業者 がおこす不誠実な事件が多いことを憂慮し、英吉利法律学校新築工 事（中央大学の前身) (明治 20/1887 年 7 月～明治 $22 / 1889$ 年 12 月) を契機として、日本最初の工事請負契約書をつくり、従来の工事請 負規定や仕様書を見直し、請負契約書の標準化を図る動きを始めて いる ${ }^{54}$ 。一方、「明治 30 年代に入っても、契約内容はともかくとし て、契約方式そのものが旧態然として、英吉利法律学校新築約定書 の影響をそこに見出すことはほとんど不可能であることを示してい る。そして民間工事にあってものどの程度までその影響が現実化し たのか、大いに疑わしいものがある。」55) と、工事請負契約の一般へ の普及については疑問とされ、建築学会では、明治 44 年 (1911) に、 建築請負契約書および工事請負契約を制定している ${ }^{56)}$ 。

與助は、明治 41 年（1908）に日本建築学会准員になっており ${ }^{57)} 、$ 明治 43 年 (1910) の魚目水産学校新築工事 ${ }^{58)}$ では、仕様書を基に木材 調書を作成し、明治 45 年 (1912) の若松尋常小学校新築工事 ${ }^{59)}$ では、 仕様書に基づいて予算仕訳書を作成し、一式請負で施工している。 すなわち、長崎県では既に、官庁工事である小学校新築工事に於い て、請負契約関係書類が採用されており、與助は、一式請負を経験 していることが判る。そのうえで、與助は、民間工事である司教館 新築工事において、天主堂工事係代人として、発注者の立場で、請 負業者と、一式請負契約書や、材料納方請負証書並びに工手間請負 契約証書、材料運搬の請負契約約関係書類を取交している。まさに、 中央において関係書類が整備過程にあるなかで、與助は、司教館工 事の現場で、請負契約関係書類を取交していることは、九州地方で、 中央における近代的請負と変わらない請負の考え方を理解し、実践 していたと考えられる。

また、写真 3 と写真 4 から明らかな様に、請負契約書の欄外に、 ローマ字で請負人の住所や、氏名などが書き込まれている。これは、 工事係の神父が仏人であり、神父は工事の計画は担当するが、長崎 における請負の事情や日本語についても不案内な点があり、材料や 職人の手配、工事や、材料、および工手間請負の業者との契約に、 與助の手助けは不可欠であったと推測される。

このような点を考慮すると、與助は、天主堂工事係代人として、 請負人に対しては、請負が守られない場合の補償と責任を求め、保 証人と保証品を要求したもので、工事全体を統括し、管理を明確に する目的で、請負契約関係書類を整備したものと考えられる。

なお、司教館工事の請負契約書は未確認であるが、ドロ神父逝去 (大正 $3 / 1914$ 年 11 月 7 日) 後に司教館は竣工していることから、與 助は、代人として工事係を全うしたものと推量される

\section{5. 司教館工事の建築工事費}




\section{（1）現金による工事費精算}

表 1 の No.9『手紙』(6 月 11 日)から、煉瓦の代金、並びに運搬 賃の支払は、この頃に発生したと考えられる。また、No. 6『領収書』 (8月 1 日) は、土工事の残金 67 円 80 銭の領収書であることから、 7 月末迄に土工事費見積 250 260 円のうち、凡そ 200 円は支払、8 月 1 日に残金を精算したことが分る。したがって、現金での支払合 計は、土工事費見積 250～260 円と煉瓦代と煉瓦の運搬賃になると考 えられる。

\section{（2）『支払伝票』による工事費精算}

表 3 は、『支払伝票』による工事項目 ${ }^{60)}$ 別の支払内訳を示してい る。表は左列から工事項目、支払伝票の冊数を表し、支払期間は当 該伝票による支払期間を示している ${ }^{61)}$

それによると、一の仮設工事費 580 円 24 銭は、足場丸太や、針金、 人夫賃などである。二の基礎工事費 3043 円 25 銭 9 厘は、福田コッ パ石 ${ }^{62)}$ や石灰や砂、セメントと、煉瓦揚賃や煉瓦工賃などである。 三の煉瓦工事費 3,412 円 23 銭 5 厘は、煉瓦代、煉瓦工賃、煉瓦揚賃、 人夫賃である。四の石工事費 821 円 5 銭 7 厘は、田結石、五島石、 西海石、鏡石と石揚賃などである。

木工事は、五・六・七であるが、五の木工事 594 円 20 銭 7 厘は、 松・セン、栂、樫、杉、塩地の他、材木揚賃、木挽賃などで主に構造材で あり、No. 11『大浦天主堂 司教館 積入明細書』の木材と運賃 304 円 33 銭も精算されている。六の木工事 2,200 円 1 厘は、松、栂、杉、 塩地、樅の他、座板などの材木代、木挽賃などで内外装工事費といえ る。七の木工事 91 円 76 銭 3 厘は、杉や木挽賃などで仕上工事費と いえる ${ }^{63)}$ 。また、長崎の村川商店 ${ }^{64)}$ や、木友商店、磯辺商店から材木 を購入している。

八の金物工事費 705 円 28 銭 5 厘は、鋸、銅板、銅釘、洋釘、ボル 卜、ナット、ワッシャ、鉄物、帯鉄、丸棒、針金、銅線、回転金物、 引戸車、樋受など多岐に亘り、鉄物や空金物、梁受金物の造り貨な どである ${ }^{65)}$ 。九の瓦工事費 1,438 円 61 銭 6 厘は、代理人小柳一 7 回 に分けて支払った瓦代、竹・縄・銅釘・銅線・瓦漆喰賃、人夫貨、
大正 3 年（1914）1 月 24 日に左官 11 人と、柴田商店への支払などで ある ${ }^{69)}$ 。十四の便所・湯場新築工事費 1,509 円 17 銭は、工手間請負 の佐藤久米次への支払と、煉瓦工、石工、大工賃の他、セメント、 竹、五島石、西海石、煉瓦の材料代と運賃、小便器と大便器各 4 個 の造り賃、取付金物、樋と電球 7 個代などである。十六の小使住宅 新築工事費 166 円 57 銭は、村川商店へ材木 15 坪代と、西海石代で ある。

この他、学便 42 円 86 銭、学湯 115 円 7 銭 5 厘、学廊・学校・階 段 205 円 83 銭 5 厘、借家 ${ }^{70)} 2$ 円 4 銭、空 11 円 40 銭、保証金 100 円、神父（チリ・ドロ・浦川） 91 円 37 銭、亦具庫・御像台 72 円 31 銭、トサ 119 円 3 銭と、数字以外で表された工事費用があり、合計 は 16, 433 円 22 銭 3 厘である。なお、「学便」は便所で石垣工事に含 まれる小便所の工事費、「学湯」は湯場で鉄川大工 8 日半貨と、長州 風呂と焚口代など、「学廊・学校・階段」は司教館 1 階と 2 階のべラ ンダ及び階段で、鉄川大工 38 日賃と、人夫賃、土管、瓦代である。 「空」は佐藤久米次へ 18 日賃であることから、空の運搬賃と考えら れ、「保証金」は納富と佐藤、小柳へ保証金の返還金で、「神父（チ リ・ドロ・浦川)」は神父に渡した費用、「弯具庫・御像台」は司教 館の収納庫、並びに祭壇工事で、この他にトサ(與助の妻)の費用と 考えられる ${ }^{71}$ 。

\section{（3）司教館建築工事費}

司教館の建築工事費は、現金で清算された 564 円 33 銭と、煉瓦代 と煉瓦や材木の運搬賃と、木挽賃、ならびに支払伝票で精算された 16, 433 円 22 銭 3 厘を併せた 16, 997 円 55 銭 3 厘を超える金額と考 えられる。

この他、No. 6 『領収書』(8月 1 日)の宛先は、「大浦天主堂 神 父ドロー様代人 鉄川與助殿」であり、No.11『大浦天主堂 司教館 積入明細書』の木材と運送料 304 円 33 銭 (8 月 21 日〜26 日) も「大 浦天主堂 鐵川與助」で、着払の契約である。また、大正 2 年 (1913) 9 月 16 日以降の『支払伝票』には、年月日、支払先、並びに目的を、

瓦莫貨で、第 1 期瓦莫代は大正 3 年 （1914）７月 14 日に矢木富三郎に支 払っている。十の塗装工事費 719 円 79 銭は、ペンキ材料、防腐㓮、 コールタール、ボイル油や、ワニ スなどの材料費 ${ }^{66)}$ と、大正 3 年 (1914) 9 月 19 日〜大正 4 年 (1915) 3 月 25 日の塗装職人山添馬之助 の支払などである。十一の硝子工 事費 75 円は、硝子 710 枚と 82 枚 代を、大正 3 年 (1914) 8 月 27 日〜 大正 4 年 (1915) 2 月 10 日に、志賀 商會 ${ }^{67)}$ に支払っている。十二の雑 費 232 円 41 銭は、大正 3 年 (1914) 3 月 7 日の建屋祝儀 ${ }^{68)}$ の他に、人 夫用茶菓子、車賃、八ケ、ホーキ コンパス、印紙、領収書、様式通 帳などの雑費や文房具費である。 十三の左官工事費 83 円 7 銭は、

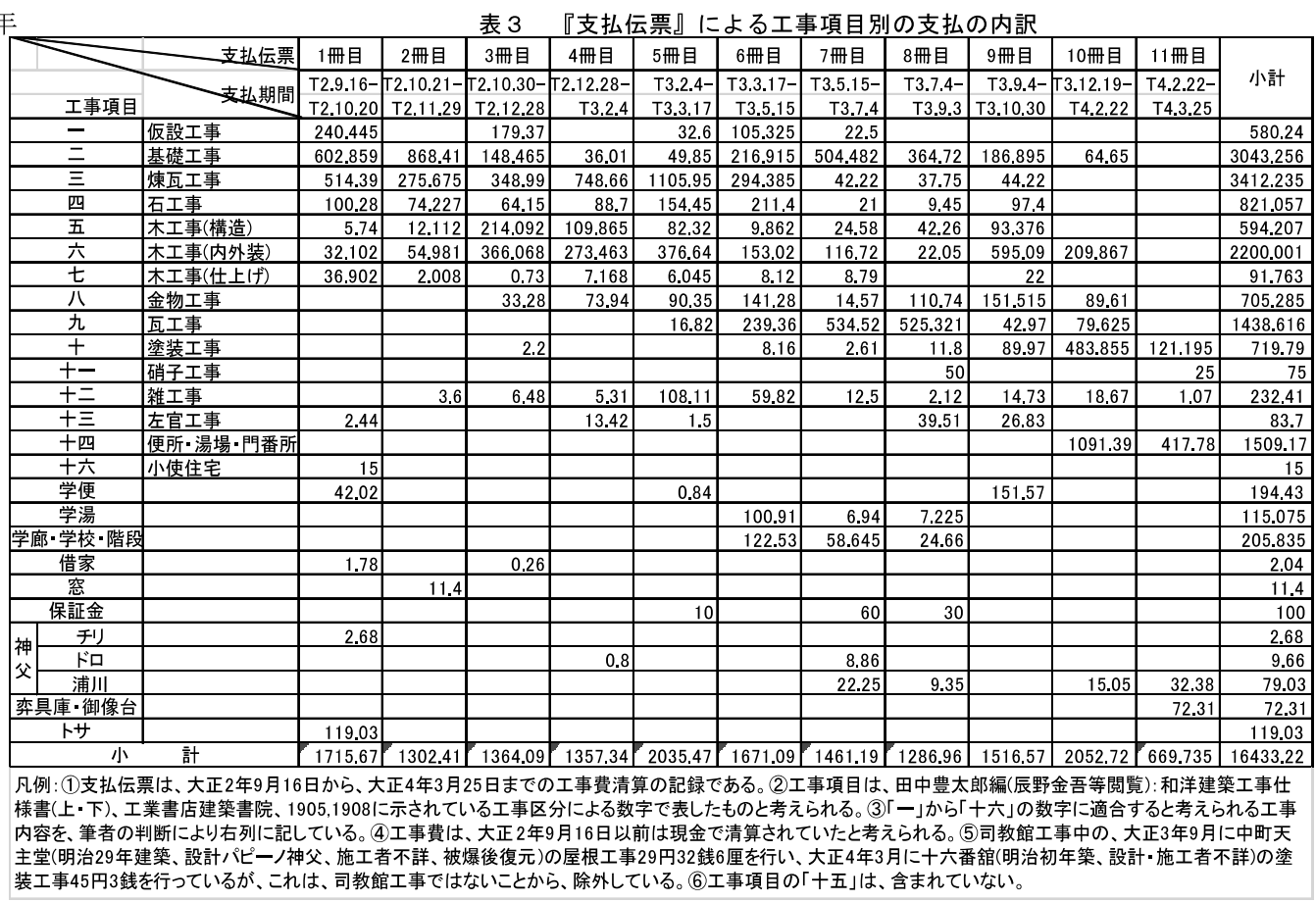


伝票に明記している。換言すると、使用目的を教会に明示したうえ で、その都度、代人である與助を経由して、教会から実費を受取る 実費精算方式 72 で精算されたもので、支払は教会である。

なお、何故、現金から『支払伝票』の精算に替わったか考察する と、今村天主堂新築工事（大正 2 年/1913）は工期が重なっており、 工事費総額は凡 3 万円となる ${ }^{73)}$ ことから、工事費総額が膨らんだこ とが『支払伝票』での精算に繫がったとはいえず、大浦教会代人に 就任した與助が、施主である教会と請負人との間で、工事費の支払 細目を明確にする目的であったと推測される。また、実費精算方式 は、予め定めた工事契約の報酬を支払う精算方式であるが、司教館 工事に関寸る與助の報酬は史料からは不詳である ${ }^{74)}$

\section{6. 司教館エ事におけるエ事工程ならびに請負者の構成 (1) 工事工程}

『支払伝票』における精算は、工事は終了後、材料費は手付など 特筆されている支払の他は、材料納入後と判断される。したがって、 支払期日とは若干のずれが予測されるが、工事工程が再現できると 考えられる。そこで、図 1 に、明治 43 年 (1910) から大正 4 年 (1915) 4 月までの司教館工事の工事工程を表している。司教館新築工事の計 画は、明治 43 年 (1910) から始められた ${ }^{75)}$ 。そこで、司教館北側の一 部を地下室にし、西側に造成した土地に小使住宅と便所・湯場を新 築する計画で、大正 2 年 (1913） 5 月と 7 月に見積をとっている。並 行して、建築材料の煉瓦、石材、木材、生石灰と砂、セメント、瓦 は発注され、大正 2 年 (1913) 6 月 11 日には、焼過煉瓦は納入段階 に入っていたといえる。また、材料納方請負契約と工手間請負契約、 材料運搬請負契約を請負人と取交している。

大正 2 年 (1913) は、入梅の前に、司教館の基礎ともなる地下室の 土掘取工事を終了し、引き続いて、石垣工事、並びに司教館の基礎 工事を行っている。仮設工事は、9 月から大正 3 年 (1914) 5 月まで行 われている。地下室は煉瓦造であることから、6月には煉瓦工事が始 まり、大正 3 年 (1914) 9 月まで行われている。煉瓦工事と並行して、 石工事が行われている。木材は大正 2 年 (1913) 8 月 21 日から順次入 荷していることから、地下室から順に上層階に向けて構造材を組立 てている。また、11月 8 日は、人夫が空を搬入していることから、 10 月末頃には空枠の取付段階に入っていたと考えられる。金物工事 は、大正 2 年 (1913) 12 月から大正 3 年 (1914) 10 月と、12 月から大 正 4 年 (1915) 2 月に行われている。大正 3 年 (1914) は、 1 月と、 7 月 から 9 月に左官工事が行われている。地下室から順に煉瓦を積み、 最後に棟を上げ、 3 月 7 日に建屋の祝儀が支払われ、 5 月から 7 月頃、 学校・階段・廊下の内外装工事が行われたと考えられる。瓦代は 6 月に支払われ、7 月 14 日に瓦莫賃が支払われていることから、この 頃、瓦工事は終わったと考えられる。硝子工事は、8月 27 日〜大正 4 年(1915) 2 月 10 日頃に行われ、並行して、塗物工事は、9 月 19 日 〜大正 4 年 (1915) 3 月 25 日頃に行われている。

便所・湯場の工事は、大正 2 年 (1913) 8 月より前に土工事が終了 し、大正 3 年 (1914) 2 月頃、空硝子を入れ、4 月に長州風呂を据え付 けている。小使住宅は、9月 24 日に 15 坪分の材木代を支払っている ことから、8月 20 日より若干遅れて落成したものと考えられる ${ }^{76)}$ 。 大正 4 年 (1915) は、3 月に、司教館の収納庫、および祭壇工事が 行われ、厨房のガス工事と、電燈の工事が行われている。以上の検

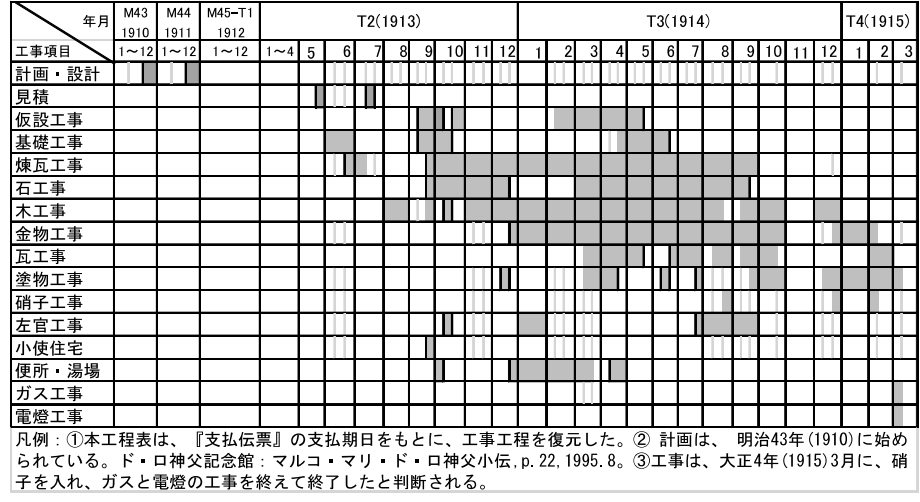

図1 司教館工事の工事工程

討から、工期は計画から凡そ 5 年程が費やされたと考えられる。

また、『小使住宅及学校附属便所并二湯場一式請負人心得書』(4-B) では、工事の落成期日は、便所・湯場は大正 2 年 (1913) 8 月 12 日、 小使住宅は大正 2 年 (1913) 8 月 20 日と決め、遅延の場合の損害金も 定めているが、『支払伝票』では、小使住宅は大正 2 年 (1913) 9 月か ら 10 月、便所・湯場は大正 3 年 (1914) 12 月から大正 4 年 (1915) 3 月に工事費を精算している。材料費や工事費の精算は、工事終了後、 もしくは材料購入時と推定すると、硝子は大正 3 年 (1914) 12 月と大 正 4 年 (1915) 2 月で、大正 4 年 (1915) 1 月に便器を製作し、3 月に 司教館の収納庫を造り、便所・湯場と閏番所の樋や、便器の取付と、 ガスと電燈工事を施工し、風呂桶と焚口は大正 4 年 (1915) 4 月に据 付けたと考えられる。すなわち、附属工事は、司教館工事の進捗状 況に併せて、本館工事の工事内容と工事工程は一緒に仕上げたもの で、工事は同時期に進められた。

\section{(2) 請負者の構成}

図 2 に、旧長崎大司教館工事における請負者の構成を示した。

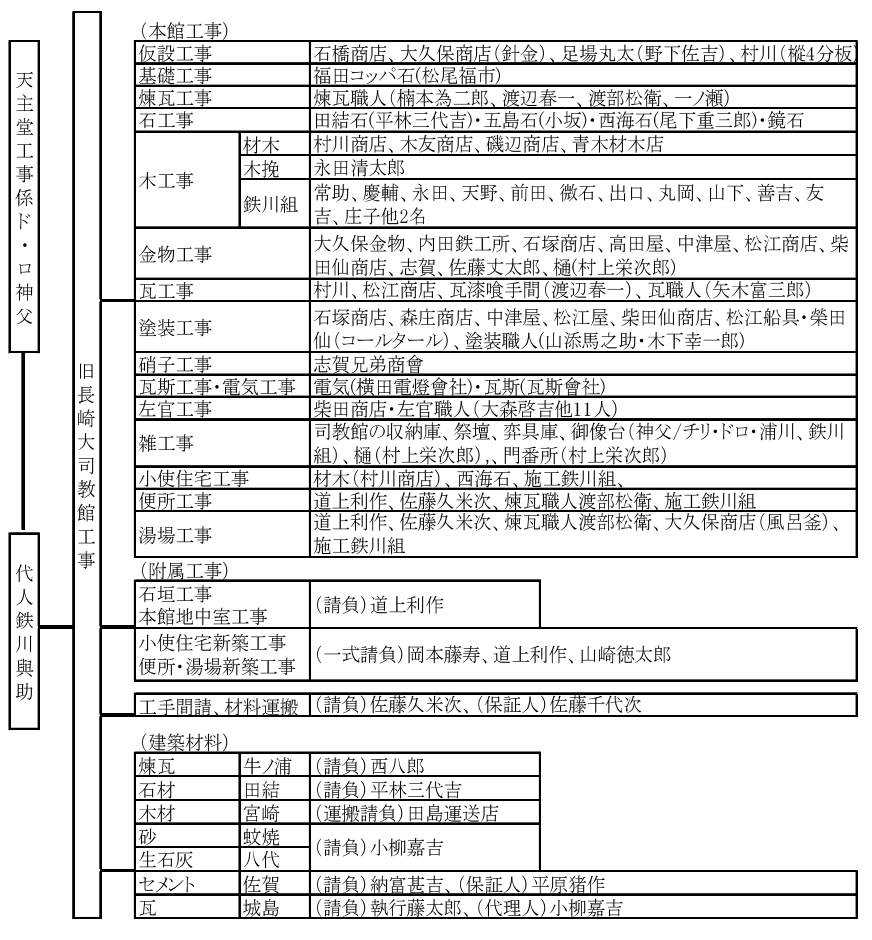

図2 旧長崎大司教館における請負者の構成

凡例: (1)旧長崎大司教館工事は、本館工事と附属工事がある。(2)本館工事にける関係者は、史料NO.17『支 払伝票』の記載内容から記入している。(3)工手間、ならびに材料運搬請負の請負人と保証人は、史料N No.10を もとに記載している。(4)建築材料は、史料NNo.7,No.11,No.13,No.14,No.15をもとに記載している。 
司教館工事の工事係はド・ロ神父で、與助は大浦天主堂工事係代 人である。本館工事は、図 1 の工事工程の項目に準じて表したもの で、内容は『支払伝票』おける支払先から記載している。附属工事 のうち、石垣工事と司教館地下室工事の請負人は道上利作である。 小使住宅と便所・湯場の新築工事は一式の工事として、岡本藤寿、 道上利作、山崎徳太郎の請負である。

主な建築材料は、煉瓦は牛ノ浦の西八郎、石材は田結の平林三代 吉、生石灰と砂は小柳嘉吉、セメントは佐賀の納富甚吉、瓦は福岡 県城島の執行藤太郎の請負である。セメントと瓦は、長崎県外の請 負人になることから、セメントは平原猪作を保証人とし、瓦は小柳 嘉吉を代理人としたと考えられる。なお、木材は宮崎の田島運送店 が運搬請負人であるが、受取人と送り主は共に與助であることから 保証人はつけていない。この他に、工手間請負、並びに建築材料運 搬請負の請負人は佐藤久米次、保証人は佐藤千代治である ${ }^{77)}$ 。

\section{7. まとめ}

司教館工事は、司教館を新築し、司教館裏手に石垣を造成し、司 教館附属工事である小使住宅と便所と湯場を新築する工事であった。 鉄川與助は、大浦天主堂工事係代人として、発注者の立場で、請

負業者と、請負契約関係書類を取交し、工事を管理している。

建築工事費は 16,997 円 55 銭 3 厘を超える金額で、大正 2 年 (1913) 9 月 16 日以前は現金で支払われ、以降は『支払伝票』で精算している。

工事費は、使用目的を教会に明示したうえで、その都度、教会か ら実費を受取る実費精算方式である。

工期は凡そ 5 年程を費やし、明治 43 年 (1910) に計画が始められ、 大正 2 年 (1913) 6 月頃基礎工事を行ない、大正 4 年 (1915) 3 月頃に、 司教館、小使住宅、便所・湯場が竣工している。

\section{謝辞}

長崎県教育庁学芸文化課、長崎市文化観光部文化財課、長崎大司 教区並びに、大浦天主堂境内管理神父梯には、ご教示を頂き、調査 には協力頂きました。また、鉄川喜一郎氏には、史料の提供を頂き ました。記してお礼を申し上げます。

注

1）大浦天主堂は現存する日本最古の天主堂建築で国宝に指定されている。カ トリック大浦教会百年祭執行委員会編 : カトリック大浦教會 百年の歩み 1965, pp. 77 116, 1965.6。日本建築学会編 : 総覧 日本の建築 9 九州沖縄 編, p. 149.1994. 2

2) Marc Marie de Rotz, (1840.3.27-1914.11.7) 仏人。カトリック宣教師。明治 元年 (1968) プチジャン神父と共に来日。大浦天主堂に石版所を設け、1971 年 から 1973 年には横浜に移り、1973 年から長崎の外海町出津に移り、司祭と して救済活動を続ける。また、建築家としても優れ、作品には旧羅典神学校、 出津教会と大野教会がある。日本キリス卜教歴史大辞典編集委員会 : 日本キ リス卜教歴史大辞典, p. 968, 1998. 8、並びに、ド・ロ神父記念館：マルコ・ マリ・ド・ロ神父小伝, 1995.8.15。

3) 日本建築学会編：総覧 日本の建築 9 九州沖縄編, p. 149.1994.2。 4) 鉄川與助 (1879 1976) は長崎県五島列島を中心に、長崎県、福岡県、佐賀 県、熊本県に数多くの教会堂を建築している。明治 12 年 (1879) 1 月 13 日長 崎県南松浦郡新魚目町丸尾鄉に大工鉄川与四郎の長男として生まれ、長崎 県南松浦郡榎津尋常小学校を卒業 (1894) 寸ると大工の修行に入る。明治 39 年 (1906) 土木建設業鉄川組設立。明治 41 年 (1908) 日本建築学会入会 (準 員) (建築雑誌 第 22 輯)。鉄川與助の入会資格は「大工」である(建築學会： 建築雑誌二百六十三號附録 建築學會會員住所姓名録, p. 90, 1908.11)。大正 2 12 年 (1913 1923) 魚目村村会議員。昭和 19 年 (1944) 鉄川組を第一土建 会社に統合。同社取締役に就任。昭和 24 年 (1949) 鉄川工務店に名称変更。
昭和 34 年 (1959) 7 月建設大臣表彰、11 月黄授褒章受章、昭和 42 年 (1967) 11 月勲五等瑞宝章受章。昭和 51 年(1976) 7 月 5 日横浜市にて没。鉄川喜一郎 氏よりの聞き取りによる。

5) 旧長崎大司教館は、当初は司祭館として建築され、現在は大浦天主堂管理 神父館拉よび神学生の寄宿舎になっており、2011 年に長崎県文化財に指定 されている。以下の文献に記載がある。日本建築学会編 : 総覧 日本の建 築 9 九州沖縄編, p. 155. 1994.2。桐敷真次郎: 大浦天主堂, 中央公論美術出 版, p. 18.1968.9 では、「司祭館の建築も、天主堂の整地も小山の仕事であっ たろう」と、大浦天主堂の請負者である小山良輔の仕事とされている。日 本放送出版協会: ある明治の福祉像ド・ロ神父の生涯, pp. 192-196, 1995.8。

6) 最初は伝道師学校として建てられ、戦後聖婢姉妹会本部となり、現在は空 家。長崎市教育委員会 : 南山手の洋館一伝統的建造物群保存地区保存対策 事業報告書, 1977。

7）「奈摩内天主堂」は、現在は、「青砂ケ浦天主堂」と名前をかえている。 8) 與助が発注者側の代人になった経緯は明らかにされていない。代人となっ た経緯を示寸資料は未発見のため調查を継続している。

9) 喜田信代, 羽深久夫 : 鉄川與助の明治期の建築経歴と桐古天主堂の請負内容, 日本建築学会計画系論文集第 566 号, pp. 161 167，2003.4。喜田信代, 羽 媣久夫, 本間博文: 冷水天主堂における鉄川與助の請負内容, 日本建築学会 計画系論文集第 568 号, pp. 133 139，2003.6。喜田信代, 羽哚久夫, 本間博 文: 奈摩内天主堂における鉄川與助の請負内容, 日本建築学会計画系論文集 第 578 号, pp. 147 154，2004. 4。喜田信代, 羽深久夫, 篠野志郎：今村天主 堂建築工事における九州地方の建築職人・鉄川與助による施工管理の実態, 日本建築学会計画系論文第 650 号, pp. 947 954, 2010.4。また、工事の精算 方式については、喜田信代, 羽梁久夫：明治期の桐古天主堂改修工事にお ける鉄川與助の工事費精算方式, 投稿中。

10)司教館は、教区本部ともいえる建物で、司教および司祭たちは司教館に住 み、事務所と住まいを兼㸚た建物といえる。長崎大司教区のご指導による。 なお、長崎司教区は、昭和 32 年 (1959) に大司教区に昇格したことにより、 長崎大司教館となっている。カトリック大浦教会百年祭執行委員会編 : カ トリック大浦教會 百年の歩み 1965，p. 145, 1965. 6. 30。

11) 大浦天主堂境内配置図には小使住宅は居宅 (その後建築された居宅も2003 年解体) と記され、長崎大司教館の西側に昭和 60 年 (1985) 建築の便所が ある。注 10) 文献 p. 172、および、大浦天主堂からの聞き取りによる。

12）與助は、史料に「地中室」と表記しているが、司教館地下室のことだと考 えられることから、本稿では地下室と表記する。

13）長崎県世界遺産登録推進室 :「長崎の教会群とキリス卜教関連遺産」構成 資産候補建造物 調查報告書, 長崎県, 2011。

14）『天主堂附属工事』については、司教館本体工事及び附属工事とする立場 もあるが、本稿では、與助の史料に沿って、司教館の附属工事とする。

15)『支払伝票』は、表紙は一部破損又は全部が欠損しており、寸法は(縦 130 ×横 $187 \times$ 厚 $8 \mathrm{~mm}$ ) で 1 冊に 100 枚が綴じられている。右側（縦 $130 \times$ 横 $53 \times$ 厚 $8 \mathrm{~mm}$ ） は「第 號、金、右金御渡被下度候也、年月日、殿」と印 刷され、ミシン目が入り切り離せる様式である。左側（縦 $130 \times$ 横 $138 \times$ 厚 $8 \mathrm{~mm}$ ）は控で「年月日、第 號、金、姓名、摘要」と記されている。伝票 の控部分の最初の頁には、鉛筆で、時系列に(1)から(11)の番号と、「司教舘」 と記され、日付、支払先、支払目的が記されていることから、司教館工事 の工事費が精算されていると考えられる。また、この伝票は「小切手」に 類似しているが、金融機関名や小切手の振出地が記入されていないため、

「小切手」ではない。なお、「支払伝票」とは、書類の整理上、筆者がつけ た名称である

16）明治期における建築工事請負は、設計と施工が分離し、見積は、新しい 建築材料と構法による積算技術が必要となり、施工の監督・指導は建築技 術者が行っている。また、工事の施工方式は、直営から一式請負に移行し、 契約関係書類も整備過程にある。建築請負については複数の文献資料があ るが、主に以下の書籍を参考にした。古川修・永井規夫・江口禎 : 新建築 学大系 44 建築生産システム, 彰国社, pp. 87-229, 1982.10。

17）熟尾九郎：近代日本建築学発達史 4 編 建築経済, pp. 581-597, 2001. 12。 18）№. 9 の手紙の宛名は「福岡県三井郡大刀洗字今村 鐵川與助殿」である が、その他は、「天主堂事務所御中」、「大浦天主堂 ドロー神父 代人 鉄 川與助」「大浦天主堂神父ドロー様 代人 鉄川與助殿」「工事係 神父 ドロー殿」、「長崎市大浦天主堂工事係」、「神父ドロー殿」、「長崎市大浦町 天主堂 鐵川與助殿」、大浦天主堂御中」、「長崎市大浦天主堂 工事係神 父ドロー殿」「大浦天主堂工事係 神父ドロー殿」と書かれている。これ は、司教館とその附属施設は大浦天主堂の敷地内にあることから、宛名に 
「大浦天主堂」と書かれたものと考えられる。

19) 本研究の史料は、與助の五男、喜一郎氏の所有する史料である。喜一郎氏 所有の図面は、川上秀人博士により「図面リスト」として整理されている が、「図面リスト」には、旧長崎大司教館の図面は含まれていない。なお、 與助の史料は、当初、関係者に分散して保管された経緯もあることから、 今後発見される可能性も捨てきれず、調査を継続していく。

20）「解体された建屋」は、撤去後、どこにどのように再利用されたかは、史 料からは確認できないことから不詳である。

21）小使住宅は、建坪 15 坪（但 6 尺 3 寸畳敷ノ坪）で、2 坪 5 合の室が 6 室あ り、「別紙図面之通り」と図面は別図で示している。建築概要は、木造住 宅 1 棟、基礎は割栗地形、コンクリート打、柱は石据、外部は板張、内部の 壁は漆喰塗、板天井で床は板張と板畳であり、屋根は棧瓦葺である。仕様 は地形之部、石方之部、木材並二大工方ノ部に分け、地形の部は、縄張、遣 形、水盛、壳掘、取設堅石割栗石の仕様を記している。コンクリートは、モ ルタルを水湿し洗砂利を充分練り合わせ、調合の割合はセメント 1 、生石灰 2、砂 4、洗砂利 10 である。石方の部は、遣方、柱石、床束石の仕様を記し、 モルタル調合割合はセメント1、生石灰 2 、砂 4 である。木材並に大工方の 部は、軸組、床組、外壁、小屋組、瓦蕞、内部仕上げ、外廻りの仕様を記し、 別に図面に示している。

22) 便所と湯場は、建坪 18 坪 6 合 7 勺で、割栗地形「コンクリート」打洗出 煉瓦腰積ミ板壁柱石据付天井ナシ内外共上鉋削リで、「別紙図面之通り」と 図面は別図で示している。仕様は遣方水盛、側通間仕切柱石下、コンクリ 一ト、遣方、煉瓦、柱下石湯場敷居石、小便所及全溜栘、大便所溜桝に分 けて記している。

23) 一式請負人心得書 36 条と一式請負証書式、工手間請負人心得書 19 条と工 手間請負証書式、材料納方請負人心得書 15 条と材料納方請負証書式が規定 されている。辰野金吾・葛西萬司共著 : 家屋建築實例，須原屋，1908.9。

24）『請負者心得』は、一小屋材八大節腐割レナキモノ瓦身八一寸二分以内 一内部見掛リ材小節材 瓦身六分以内 但し天井材建具材見掛リ鴨無節正 角材一外部身係リ材大節腐割レナキモノ身瓦一寸以内 一釘大小共正規 ノ寸法ノモノヨ仕用スル事 一図面卜仕様卜相違ノ所八係員ノ指揮二従つ 事。『請負者心得』(4-A)には、小屋材、内装材、外装材は大節や腐割れが 無いもので、天井材、建具材は小節がないもの、釘は正規の寸法のものを 用い、図面と仕様と違う所は係員の指揮に従うとされている。

25）『小使住宅及學校附属便所并二湯場 一式請負人心得書』は、以下の 11 項目が墨書されている。1．材料は新材を用い、大節や腐れ割れの無いもの で、見える所は 全部鉋削りし、但し便所の床は見えないけれど鉋削りを し、天井と建具材は節のない角材とする事。2. 鉄物や釘は正規の寸法のも のを使用する事。3．些かな部分と雖も本工事附帯のものは総て指揮の通り 請負費内で、仕様や図面中に不明瞭な点は掛員の指示に隋い着手する事。 4. 工事中の取締その他危険な場合に際しては、予防を命じる事。5. 建築 材料及び物品は掛員の検査を受ける事。6. 係員の指示に従わない職工は、 直に工場の出入を差止める事。7. 工事は逐次出来た部分から充分保護し損 傷を防ぐ事。8. 同一種類が 2 個以上ある場合は、先づ 1 個を仕上げ、検査 を経た後、全部に着手する事。9. 工事の落成は学校附属便所と湯場は本年 8 月 12 日、小使住宅は本年 8 月 20 日とする。10.請負代金の払渡は、材 料は全部を工場に持込んだ上で全金額の $1 / 3$ 、建家は瓦莫の上で $1 / 3$ 、落成 した上で残金を拂渡す事。11，心得書に請負人が違背し当方へ損害をかけ た時は、何条に限らず係員はその損害額を調査し、倍額を請負人に支拂は せる事。大正武年七月十七日 請負人 岡本藤寿印 右圭 道上利作印 右全山崎徳太郎迎 大浦天主王神父ドロー様 代人 鉄川與助殿

26）「一金壱千円 建家棟数等別紙図 面及七仕様書之通り 右今般長菩市 大浦南山手乙壱 番地御指定ノ所へ御新築被成候 工事一式請負申候義実 正也然ル上八 御下渡シノ図面并二仕様候及ビ大浦天 主堂工事請負人心 得書共固ク相守リ申可候依而契約書一札如件」である。

27)「大浦天主堂工事請負人心得書」の書類名では筆者は未確認である。司教 館は大浦天主堂境内にあることから、司教館工事における請負人心得書を 示したものと考えられる。

28）『材料納方請負人心得書』は15 条で、『家屋建築實例』と同文である。 辰野金吾・葛西萬司共著：家屋建築實例，須原屋，pp. 34-39, 1908.9。

29)『材料納方請負証書式』(8-B) は、材料別に請負金額、内訳、材料種別、 個数、納入期限、身元保証品を記入する書式であるが、これらは未記入で ある。引き続き、「長崎市大浦南山手乙壱番地の附属工事にあたり、前記御 建築材料納方請負を仰せつかり、請負にあたっては、御注文書、材料納方 請負人心得書を遵守し誠実を旨とし、前記日限通りにそれぞれ納入し、万 一、その一部でも約定日限に納付できない時は日限後、皆済迄、5 日毎に 請負総金高の $2 / 100$ を差出し、前記身元保証人を立て保証品売却の上、そ
の代金を支払、保証人は本人と連帯責任を負う」とあり、請負が守られな い場合の保証と責任も定めている。他の『材料納方請負証書式』には日付、 請負人の住所・氏名を記し捺印しているが、石材の証書には記載がない。

30)『工手間請負証書式』は、「而手間請負人心得書繪圖面仕様書等 遵守シ誠 実习旨トシ着般ノ都度無相違運搬 仕候万日限习怠タリ候節八日限后五日 毎二講 負総高ノ壱百分ノ武 7 差出可申候而前記 身元保証金差シ入レ左 二署名スル保証人相立 申候若シ自分ヨリ貴工事係へ支拂フベキ金 円 支拂ハザルトキハ保証金ヨ以テ右支拂ヒ二御 充用被下度又保証人八総而 八事項二付本人 $卜$ 連隊責任 7 負 年八月三日 長崎市銭座町二丁目壱百拾番地 佐藤久米次卵 長崎市小島 七百七拾八番地 保証人 佐藤千代次 長崎市大浦店天主堂工事係 神父 ドロー様 總高凡金二百四拾円位」である。

31）『建築材料運搬請負証書』は、

\section{「一木材運搬壱肩二付金五銭也}

一全壱肩二付金七銭也

一全壱肩二付金参銭也

一全壱肩二付金四銭也

一全壱肩二付金参銭也

一 停車場 $コ$ 下置場迄之賃銭

二 停車場 $コ$ 現場迄ノ賃銭

三 下置場ヨリ現場迄ノ賃銭

四波止場ヨリ現場迄ノ賃銭

五 波止場ヨリ下置場迄ノ賃銭

但シ水揚並二貨車下ロショリ現場積 立テ迄ノコト 尚弁天ノ置場ヨリ ノ運搬卜停車場ヨリノ 運搬卜ハ同一ナル事」と停車場から、現場までの 運搬経路と運賃を取り決め、「但シ身元保証金八煉瓦並に石材揚ケ賃二 對 スル保証金ヨ本証書ニモ流用願上候」とある。

32）桐古天主堂と奈摩内天主堂工事には西八郎の牛之浦煉瓦を用いている。

33) 『煉瓦石買入注文書』(7-C) は、煉瓦 15 万個（但し上等 3 割、中等 5 割、 下等 2 割とし、上等と中等下等の 2 種に取り分ける) と、焼過煉瓦 3 万個 (但 し上等 3 割、中等 4 割、下等 3 割とし、上等と中等下等の 2 種に取り分ける) の注文書で、見本の通りの品質に限り、代金は現品の納入高に応じ掛渡し、 残金は皆納入の後支払う注文である。発注者、請負人の押印はなく、注文内 容を写した書面である。

34)『石材買入注文書』(8-C) は、肥前北高来郡の田結産注34の楷段石、入口敷 居石、空血石、沓石、地覆石、迫石の注文で、入口敷居石の納期は 9 月 15 日、迫石の納期は 10 月 15 日、その他は 10 月 10 日の納期であり、石材は見 本の通りの品質で斑がない上等品に限り、納品は海岸へ着船の上、検査を受 けるもので、発注者、請負人の押印はなく、注文内容を写した書面である。 $35)$ 南高来郡田結 : 明治 22 年〜昭和 30 年(1889-1955)の長崎県北高来郡の自 治体名。角川日本地名大辞典」編集委員会編: 角川日本地名大辞典 42 長 崎県, p. $616,1987.7$ 。

36) No. 8 の石材の書類の見開きの頁に割印があるが判読困難である。支払伝 票の大正 2 年 9 月 29 日以降、平林三代吉は、田結産石材を納入している。 37) 八代は、熊本県中部、八代海に臨む工業地带。石灰石資源を背景に関連企 業が立地した。相賀徹夫 : 万有百科大事典 8, p. 1130, 1974. 2。

38)『砂買入注文書』(13-B) は、砂凡 50 坪の注文書で、砂栘は長さ 12 尺、巾 6 尺、高さ 3 尺で納期は 12 月 30 日とし、初回の納入は 9 月 20 日で、雨天 を除き 7 日間に 7 坪を完納し、引き続き栘が空いた時は雨天を除き 5 日間 に 4 坪を納めるとしている。

39) 瓦石炭販賈 久留米絣製造業である。

40）『領収書』の内訳は以下の通りである。一金 参円六拾銭 石工四人、 一企 武円四拾銭 男夫四人、一全九拾銭 女三人、一企壱円武拾銭 石灰小俵拾俵、一全 七拾銭 セメン七升、一全 八拾銭 左官壱人、一 全 武拾壱銭 砂三ケ、 九九円拾壱銭 但シ下水ノ分と、一金 参円 地ナラシ、一全 参円六拾銭 張石、一全 参円 石垣上下 下水ノ天川、 一全壱円 小便所間仕切石代、一全 武円 小便溜栘、一企 武円拾 銭 石垣 高壱尺 長サ凡十二間、計 拾四円七拾銭、合計 武拾舟 [ママ]参円、外二四円五拾銭、武拾七円五十銭ノ所

41）手紙は「ド・ロ神父書簡」として、既に公開されている。博物館明治村編： 明治のキリシタン一信仰のかたちと心一, 名古屋鉄道会, p. 59, 1994. 9。その 内容は「拝啓 梅雨の候二候得共益々御健勝奉賀候御注文の焼過ぎ煉瓦一 萬個 到着仕候 代價は壱個壱銭 個一厘四毛の送状に接し候 荷揚げの為めに者石工道上某 に週旋を頼み 候度壱個に付 天主堂境内まで一厘式毛にて 貴下と契約整ひ居り候由 申候運送船の到着の節八 日曜日に當り居り候を以て荷揚げ 滞り申候故 船主は急ぎ且又波止場 八假り置場の許可無之候故船より 且つ且荷揚げ するを船主にて好ま ざるより 武円の水揚げ賃を出して近傍の明地二荷 揚致候由 此水揚げ賃は誰の負擔に属す 心゙きか貴下より何の通知も 無 之候故 実に困却し居候間 右煉瓦の件二付至急明細なる 御通知あらん 
ことを希求仕候 大正二年六月十日 敬具 二伸 煉瓦の代金八誰れに又 何日支払ふべきか 鉄川與助殿 長崎大浦天主堂 ドロ抨」である。

42) 與助は、大正 2 年（1913）は、今村天主堂新築工事に従事している。喜田 信代, 平井聖, 本間博文, 羽深久夫 : 桐古天主堂 - 冷水天主堂·奈摩内天主堂 · 今村天主堂の建築工事における関与した人々と鉄川與助の役割, 日本建築学 会大会学術講演梗概集 (近畿), pp. 199〜120, 2005.9。

43）『杉挽立材買入注文書』は拭板用上小節片面赤身、『松挽立材買入注文書』 は小屋及 2 階根太材、『杉挽立材買入注文書』は柱床枠材で、木質は上等で 大節や節腐、割れや曲がり、捻れのない木材を持ち込みの上、1 本毎に検査 を受け指示の場所に積み立てるとしている。『煉瓦石買入注文書』は、煉 瓦を上等煉瓦石とし、寸法（長さ・幅・厚）を明示したうえで、「煉瓦石八 見本ノ通リノ品質」で、疵捻れの無く、斑が無い上等品に限り、納品は建築 現場の指揮の場所へ持ち込み検査を受け、納期、支払についても記す書式で ある。『石材買入注文書』は、石の産地と寸法を記し、斑が無い上等品に 限り、納品は建築現場の指揮の場所へ持ち込み検査を受け積み立てるとして いる。『砂買入注文書』は、砂は土気を混ぜない塩分の少ないもので、納 品は建築場に持ち込み検査を受けるとし、砂桝の長さと幅、高さを指示し、 栘入れの人夫、栘底の掃除、栘の破損修緬は請負者の負担としている。『生 石灰買入注文書』は、焼立生石灰 100 貫目で、八代産品質見本の通り最良の 焼立生石死を購買し、石灰は沸化した後篩粕、又は生々焼石等、最良の正味 と引換えるものであり、節片は最初 2 分 5 厘の目篩に掛け、その粕を小蛸で 砕き、同様に篩に掛け残った粕を砕き同様に篩に掛け、その残り粕を引換え、 納品は指定の員数を通知の日より 20 日以内に建築場内の指図の場所入持込 み検査を受け積立てて置くとしている。『セメント買入注文書』は、「セ メント (ホートラシト)」の品質は鉄道院の規定に合格したものである事、 納品は指定の数量を建築場内指図の場所入持込み、検查を受ける事、納入期 限は工事の都合により納期を伸縮する事がある、納期を誤り工事に支障を生 じた場合は、相当の損害を償う事である。

44) 煉瓦の員数調査は、現状の立面写真、及び壁厚から数量の確認を行った。 45) 田中豊太郎編（辰野金吾、妻木頼黄博士、三橋四郎の閲覧）：工業書店建 築書院, p. 125, p. 127, 1905。

46) 長崎には古くから独特の建築材料として、天川 (アマカワ) 土に貝灰を混ぜ た天川漆喰という工方があった。山口光臣 : 長崎の洋風建築, 長崎市教育委 員会編, pp. 88-89, 1967.3。天川漆喰は、赤土が溶け煉瓦の目地が溶けだす ことから、ド・ロ神父は、石灰と砂をこ祮合わせた「ド・ロ壁」を採用し た。日本放送出版協会：ある明治の福祉像 ド・ロ神父の生涯, pp. 193-195, 1995.8。

47) 畑中建三編: 土木建築工事請負便覧, 大蔵書院, 1914. 3 のノートの頁に、「ド ロー様」と「煉瓦卜口調合割合 佐野博士実験」と比較して記している。

48) 筑後三㒂郡城島町に荒木貞次郎が瓦工場を営んでおり、今村天主堂新築工 事に納入している。

49)福岡県久留米市の城島では、明治期以降の手造り時代の型を基に、現在 も製造を継続しており、その所要量は 1 坪に 65 枚が基本である。久留米市 城島の瓦製造業 今村銀色よりの聞き取りによる。

50) 床面積等は、長崎県教育庁学芸文化課のご教示による。

51) 菜の畳床を使わないで板に畳裏を貼り付けた代用の畳。彰国社 : 建築大辞 典第 2 版, p. 79, 1998.4。

52) 生石灰と砂の身元保証品は、佐世保銀行長崎支店小口当座預金通帳 1 冊で、 預金額は 50 円 9 銭である。セメントの保証人は平原猪作であり、身元保証 品は80 円である。瓦はNo.16『預り証』から明らかな通り、瓦請負身元 保証金 50 円の預り証である。

53) 永井久雄 : 近代日本建築学発達史 4 編 建築経済, pp. 673-675, 2001. 12。

54) 辰野金吾らの設計による英吉利法律学校 (中央大学の前身) (明治 20/1887 年 7 月〜明治 $22 / 1889$ 年 12 月) では、日本最初の工事請負契約書をつくっ た。これは、辰野金吾が、英国王立建築協会のものに擬した工事請負契約 書を作成して取交したものである。清水建設百五十年史編纂委員会 : 清水 建設 150 年史, pp. 68-69, 1953.11。

55) 城谷豊 : 近代日本建築学発達史 4 編 建築経済, pp. 581-583, 2001. 12。 56)城谷豊：近代日本建築学発達史 4 編 建築経済, pp. 578-580, 2001. 12。

57) 與助は、明治 41 年 (1908) に塚本靖の紹介で日本建築学会准員になってい る (建築雑誌第 22 輯)。なお與助の入会資格は「大工」である。建築學会 : 建築雑誌二百六十三號附録 建築學會會員住所姓名録, p. 90, 1908.11。

58) 喜一郎氏所有の史料には、魚目水産学校新築工事（発注者は魚目村長、施 工場所は長崎県南松浦郡魚目村）の「魚目水産学校新築仕様設計書」と図 面があり、鉄川工務店工事経歴書には、実績として記載されている。

59) 喜一郎氏所有の史料には、長崎県南松浦若松村の若松村立尋常小学校新築
工事（発注者は、若松村長、施工場所は長崎県南松浦郡若松村）関係書類 があり、鉄川工務店工事経歴書には、実績として記載されている。書類は (1)『明治四拾参年第四月 若松村立尋常小学校校舎住宅及附属家新築工事 仕様書 五島魚目鉄川用』、(2)『明治四拾三年第四月 若松村立尋常小学校 新築工事費豫算仕譯書 五島魚目 鉄川用』、（3)『明治四拾三年第三月着 一式請負人心得書 若松村立尋常小学校新築工事用 五島魚目 鉄川用』 で、いずれも発注者および請負人の署名捺印はない事から写と判断される。 60) 田中豊太郎編（辰野金吾、妻木頼黄博士、三橋四郎の閲覧）: 和洋建築工 事仕様設計實例 上・下：工業書店建築書院，1905、および 1908 では、工 事項目を、それぞれ数字で表している。支払伝票で書き分けられた「一か ら十六」の漢数字は、司教館工事における工事項目をあらわしていると考 えられることから、支払内容から工事項目を数字の右列に示している。

61）『支払伝票』に記された数字は工事項目と考えられることから、その支 払先や支払の内訳から、筆者が判断したものである。

62) 福田コッパ石は福田岬より産出する石材で、大正時代は松尾福市、田尻喜 三郎が権利を持っていた。林純夫 : 福田村郷土史一大村藩郷村記にみる生 活一, pp. 188-189，2000.5。支払伝票では松尾福市に支払らわれている。

63)他に、三重砂運賃 22 円が含まれている。

64)村川朝松が、明治 45 年 (1912) に製材所を創業し、現在は材木商として出 島町で営業を継続している。

65) 取引先は、大久保金物（現在も長崎市で操業）、内田鉄工所、石塚商店、 高田屋、中津屋、松江商店、柴田仙商店、志賀、佐藤丈太郎である。

66) 取引先は、石塚商店、森庄商店、中津屋、松江屋、柴田仙商店、松江船具 である。

67) 江戸町にガラス商の志賀兄弟商會があり、與助の史料にカタログがある。 68 ) 祝儀は、請負人や臨時雇人夫、煉瓦工と石工、女人夫、木挽と鉄川組に分 けて合計 97 円 85 銭が支払われている。鉄川組大工と木挽一は、永田 3 円 前 田 2 円常助 4 円 慶輔 4 円 永田 2 円 50 銭 天野 2 円 50 銭 前田 2 円武 石 2 円出口 2 円 丸岡 2 円 山下 2 円前田 2 円善吉 2 円 50 銭 友吉 2 円 50 銭 庄司 50 銭 永田 50 銭 外 2 円で支払合計は 37 円である。

69)この他に、煉瓦揚賃と敷瓦 200 枚代、鉄川大工手間 11 日賃、スサ、ガラ ス、土管、銅製水パイプ代があり、これらは湯場の工事費と考えられるが、 左官工事費として精算されている。

70）「借家」については、何を示しているのか現状では不詳である。

71）與助の妻卜サの費用は、松江商店の買物代金である。

72) 実費精算に関しては参考文献における表記もまちまちであるが、本稿で は「実費精算方式」と表記する。ちなみに、稲垣栄三 : 日本の近代建築 [z の成立過程（下), 鹿島出版会, pp. 49-70, 1979.6 は、「実費精算方式」とし ている。山下壽郎氏は「実費報酬加算式施工契約」とし、「工事の担当者が 建築工事を施工し、之に対して、利益をこめない実際の費用だけを建築主 に負担せしめ、これと同等に従来の利益に替えて、自分の労務に対して適 当なる報酬を建築主に出して鿓う」契約である（山下壽郎：報酬加算式建 築施工契約制度, 彰国社, p. 4, 1966.7) としている。この他、彰国社編 : 建 築大辞典第 2 版, 彰国社, p. 713, 1998. 4 では、「実費精算契約」としており、

「注文者が施工者に施工を委任し、施工の為に費消した実際の費用と予め 定めた手数料としての報酬を施工者に支払う契約方式。(中略) 我国では形 式的な実費精算契約は殆ど行われていない。」とある。

73 ) 今村天主堂新築工事（大正 2 年/1913）では、『新築工事預算書』は 2 万 1723 円 32 銭 5 厘（1 万 8989 円 32 銭 5 厘と人夫賃 2734 円）で、この他に 基礎工事の追加工事費があり、総額は凡 3 万円程となる見込み。

74）司教館工事における與助の請負金については、今後も、史料の収集に努め、 明らかにしたい。

$75)$ 明治 43 年 (1910) 長崎大浦司教館の設計、建築監督とある。ド・ロ神父記 念館：マルコ・マリ・ド・ロ神父小伝, p. 22, 1995.8。また、日本放送出版 協会：ある明治の福祉像 ド・ロ神父の生涯, pp. 232-233, 1995.8には、 明治 44 年 (1911) 9 月 18 日、クーザン司教の没後、ド・ロ神父最後の仕事 として、「司教館の設計、監督に従事した」とある。

76)解体工事の実施時期は不詳であるが、司教館工事が進行していると判断さ れることから、予定通りに終了したものと考えられる。

77) 工事、並びに材料の請負業者については、西駒太郎は、長崎県東彼杵郡江 上村で「牛ノ浦煉化」工場を営業しており、奈摩内天主堂新築工事におい て煉瓦を納めている。その他についても調査したが、現段階では特定に至 っていないことから、今後も引き続き調査を継続していく。 


\title{
A REPORT ON THE BUILDING CONSTRUCTION WORK AT THE FORMER HOUSE OF THE ARCHBISHOP OF NAGASAKI
}

Nobuyo KITA* and Hisao HABUKA**

\author{
* Graduate Student, Graduate School of Design, Sapporo City University, M.A. \\ ** Prof., Graduate School of Design, Sapporo City University, Dr. Eng.
}

Construction work at the Former House of the Archbishop of Nagasaki entailed the erection of a stone wall behind the house, and new quarters, toilets, and a basement for the servants. These constructions preceded the renovation of the Former House of Archbishop.

Yosuke Tetsukawa, an attorney of the construction team at Oura Cathedral, signed contractual agreements with the contractors and supervised the construction work. The construction cost exceeded 16,997.553 yen, with cash payments administered prior to September 16, 1913, and "payment slips" thereafter.

The construction costing included the actual cost plus a fee contract system, in which the contractors disclosed the purposes of the expenditure to the Church, and the Church met the actual cost on each occasion.

Planning of the renovations began in 1910, and the construction was completed around March 1915. Therefore, the entire project spanned five years.

（2014年 2 月 4 日原稿受理，2014年 5 月19日採用決定） 